\title{
Critical Analysis of Public Debt and Tendencies of Its Management
}

\author{
Žaneta Karazijienè \\ Mykolas Romeris University \\ Ateities str. 20, LT-08303 Vilnius \\ DOI:10.13165/VPA-15-14-2-03
}

\begin{abstract}
One of the most important factors in the macroeconomic system of every country is public debt. This is due to the processes of debt forming and its servicing has a significant influence to the financial system, the investment climate, the consumption structure and the development of the international corporation. The most common reason of the public debt and its increase is the existing policy which cannot ensure a steady balance of the state revenue and expenditure. A variety of theoretical concepts of the public debt management, scientists' attitude towards the public debt, critical indicators (selected according to indicators defined in the Maastricht Treaty and in accordance with the International Monetary Fund and the World Bank requirements) of the acceptability assessment of the public debt are analysed in this article. On the basis of identified critical indicators of the public debt acceptability, the critical analysis of Lithuanian borrowing tendencies and assessment of indicators is performed. The results revealed that Lithuania is often provided for non-compliance with the criteria approved by the Maastricht Treaty or the International Monetary Fund and the World Bank. The mathematical modelling of the Lithuanian public debt projections indicated that a tendency of a positive downward on the Lithuanian public debt share of GDP is likely to happen in the future.
\end{abstract}

Keywords: debt, debt management, budget, deficit, state policy and regulation

Raktažodžiai: skola, skolos valdymas, biudžetas, deficitas, valstybès politika ir reguliavimas

\section{Introduction}

Lithuania, as many other European countries, is constantly facing the lack of financial resources, therefore, the public borrowing both abroad and within the 
state occupies a significant role in strengthening the financial system and providing the necessary funds [14]. The long-term economic development may be ensured by using effectively opportunities of the public borrowing funds. The public borrowing in countries with transition economy is an effective way of development: the public uses the borrowed funds for economic growth, sustainable development of the society and for other similar purposes [24].

In recent years, a very rapid increase of the public debt has been indicated in many countries. The world practise shows that more and more funds of the national budget are allocated for old debts rather than investments.

Economy of Lithuania has grown consistently every year since 2004. Nevertheless, the Government has still failed to form the balanced budget. The increasing deficit of the budget occurred as an increased requirement of borrowing. The economic downturn in 2008 very strongly affected the financial and macroeconomic environment in Lithuania. Because of rising unemployment, failure to collect taxes, expenditure in the sphere of the social security, etc., the necessity to borrow appeared to the Government. Therefore, the Lithuanian public debt more than doubled during the period of 2008-2011 - from LTL 17 billion to LTL 41 billion. Since that time, the debt is further increasing and in 2013 it was amounted to LTL 47 billion or 39 percent of GDP. On the one hand, it is a quite good and even the model indicator because the EU countries average of the public debt was 85,4 percent compared to GDP in 2013. On the other hand, the debt is still growing and it requires more and more funds to service it, therefore, a risk occurs that the state will not be able to meet its future obligations. Lately, the public space has been raising a number of discussions, arguments, objections and concerns on the management policy of the public debt. Therefore, it is difficult to assess and implement correctly and unambiguously the policy of the debt management in Lithuania, especially when this policy may greatly affect the social development of economic and society in the future.

The aim of the article is to perform the critical analysis of the management tendencies of the Lithuanian public debt in accordance with a variety of theoretical concepts of the public debt management.

Research methods include systematic and comparative analysis and summary of the scientific literature, method of logical deduction, statistical benchmarking analysis, conclusions generation method, mathematical modelling and visualization techniques.

\section{A variety of theoretical concepts of public debt management}

In Lithuania, as well as in many countries of the world, borrowing occupies a special place in the financial system, as it is the second most important source of income after the tax receipt and the main instrument for covering the deficit of the budget. Most countries typically find their government budget in deficit rather than surplus, so that the amount of worldwide government debt has been growing over 
time [10]. According to the Lithuanian law, the public debt is defined as follows: Public debt - assumed, but not yet implemented obligations by, entitled to borrow, general governments entities', to repay creditors their funds, which have been borrowed by distributing Government's securities, by signing loan agreements, financial lease (leasing) contracts and other debt instruments, with a consolidated sum [17]. The scientific literature provides many theoretical concepts of the public debt (see Table 1).

Definitions of public debt, presented in Table 1, can be divided into two categories. The division can be processed, according to the emphasized subject, describing public debt. Authors, who define public debt as being related to budget imbalance, can be assigned to the first group; while authors, depicting the concept of public debt as the total amount of state's highest authorities' existing loans and their maintenance costs, can be ascribed to the second group. According to such grouping principal, O. Blanchard, N.G. Mankiw and P. Taylor, G. Davulis, J. R. Barro and their definitions fall into the first category; and public debt definitions, provided by K. Levišauskaitè and G. Rūškys, Ž. Štuopyte and A. Guzavičiaus, E. Buškevičiūtè and V. Snieška, fall into the second one.

\section{Table 1. Concept of public debt, presented by different authors}

\begin{tabular}{|l|l|}
\hline \multicolumn{1}{|c|}{ Author } & \multicolumn{1}{c|}{ Concept of public debt } \\
\hline $\begin{array}{l}\text { Levišauskaite, K., and } \\
\text { Rūškys, G. (2003) }\end{array}$ & $\begin{array}{l}\text { Public debt - it is a sum of all issued and uncovered state } \\
\text { loans along with accrued interests that must be paid on fixed } \\
\text { time or before the deadline. }\end{array}$ \\
\hline Snieška, V., et al. (2005) & $\begin{array}{l}\text { Public (government) debt - debt of all Government's levels, } \\
\text { during the financial year. }\end{array}$ \\
\hline $\begin{array}{l}\text { Mankiw, N.G., and Taylor, P. } \\
\text { (2006) }\end{array}$ & $\begin{array}{l}\text { Governments finance budget deficits by borrowing in the } \\
\text { bond market, and the accumulations of past government } \\
\text { borrowing is called the government debt. }\end{array}$ \\
\hline Blanchard, O. (2007) & $\begin{array}{l}\text { Public debt is the amount of the reserve - current debt that } \\
\text { government has accumulated, because of the former deficit. }\end{array}$ \\
\hline $\begin{array}{l}\text { Štuopyte, Ž., and Guzavičius, } \\
\text { A. (2008) }\end{array}$ & $\begin{array}{l}\text { Public debt - is the sum of government's non-refundable } \\
\text { loans and unpaid interests for them, and other financial } \\
\text { liabilities that the state has undertaken to its creditors. }\end{array}$ \\
\hline Barro, J. R. (2008) & $\begin{array}{l}\text { Public debt - is the sum of state's debt securities, intended to } \\
\text { finance a temporary lack of funds in the state budget. }\end{array}$ \\
\hline Buškevičiūtė, E. (2008) & $\begin{array}{l}\text { Public debt is specific crediting relationships, emerging } \\
\text { among the entities, residents and state. }\end{array}$ \\
\hline Davulis, G. (2009) & $\begin{array}{l}\text { Public debt - the amount of state's total uncovered annual } \\
\text { budget deficits. }\end{array}$ \\
\hline
\end{tabular}

Source: compiled by the author [15], [25], [23], [3], [26], [2], [6], [7] 
There is no one general theory on the public debt but there are several theories that differ in a variety of assumptions, ideological positions of the authors, attitudes and conclusions. The main object of the debate about the public debt is its impact on the economy. Six theories which deal with the debt in this context are provided below [1].

The Classical theory argues that the state destroys the capital by taking loans and creates the debt burden on the future generations. This burden is the additional charge in the future that has to be collected in order to pay interest and repay the debt. A country would be richer without the debt. The debt burden on the future generations will be justified only when the Government will use these borrowed funds to the production of the public goods.

The Functional Finance theory claims that the future generations will get requirements (to receive interest) and liabilities (to pay taxes) from the current loans. The future generations do not get a burden because the requirements are equal to liabilities (at least in the case of the domestic debt). In principle, the loan is some form of tax and, in many cases, it is an ideal form.

The Crowding-out theory states that a bad debt has a significant impact to the economy because the country paying the deficit of the budget with loans crowds out the private borrowers from the credit market and, thus, holds back the private investments. Today, it is a standard approach to the economic impact of the debt.

The Ricardian Equivalence theory (a hypothesis, a theorem) states that there is no difference in the economy how the country is covering its expanses - by taxes or by borrowing. Investments would not change if, for example, taxes were reduced in X dollars and at the same time X dollars were borrowed in order to keep the expenditure of the country at the same level. This is a non-standard approach to the economic impact of the debt.

The Tax Smoothing theory argues that the deficit of the budget (including loans) allows tax rates do not change over time. The country collects taxes from citizens and at the same time increases their wealth by weakening the distortive effect of taxes. This theory is very popular among economists and is important to the creators of the fiscal policy [1].

These theories examine the actual impact of the debt on the economy. Prices are stable (except prices of the credit in the Crowding-out theory). As for the Fiscal theory of the price level, inflation has become a fiscal phenomenon when the country borrows and the Central Bank is issuing a new emission of money in order to reduce the value of the money borrowed. This theory links the price level with the nominal accumulated debt and the future budget surplus which will be necessary for the repayment of the debt.

It is very important to evaluate the components of the public debt. Figure 1 shows the structure of the public debt described by the majority of the authors.

According to Levišauskaite and Rūškys [15], the public debt is divided into direct (direct liabilities taken on behalf of the country - distribution of the 
Government securities in the financial markets, borrowing from banks) and indirect (guarantees of the country, i.e., the country assumes the financial liability to repay the loan if the borrower fails to fulfil debt liabilities) debts.

In turn, direct and indirect debts are divided into domestic (liabilities that are formed in the domestic market and accepting to LTL) and foreign (liabilities that are formed in the overseas market and accepting to the foreign currency) debts.

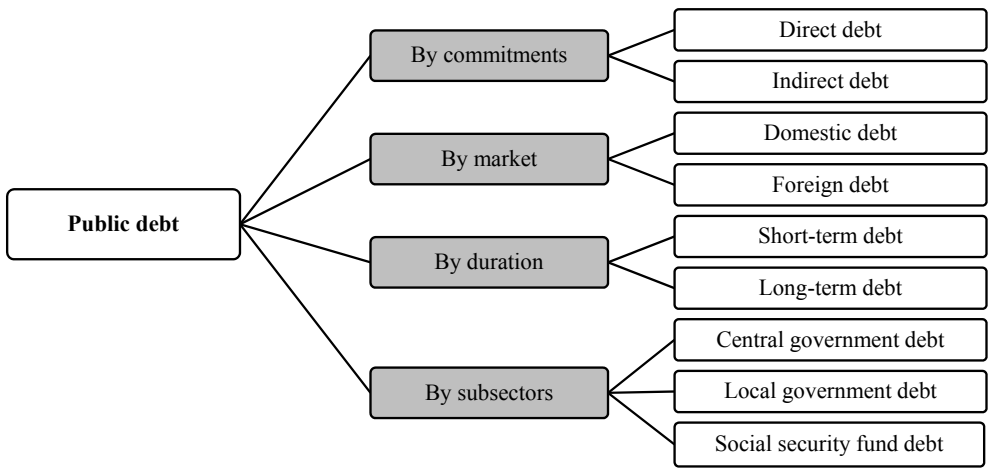

Figure 1. Structure of public debt

Source: compiled by the author

According to the duration of the public debt, it can be short-term (residual maturity of up to one year) and long-term (residual maturity of more than one year). Karazijiene and Saboniene [13] emphasise that it is not very convenient to borrow for a short-term period because then the Public Treasury should plan benefits more commonly and sometimes sell new borrowed instruments in the market in order to pay earlier debts. From another perspective, the long-term debts are a bit more expensive than the short-term debts because of their higher rates of interest and, therefore, it can be stated that the Treasury is limited to borrow for the longer period because of this aspect.

The Lithuanian public debt is also structurally divided into the central government debt (it is the debt of country enterprises, non-budgetary funds, budgetary and public enterprises; usually, this debt makes about 80-90 percent of all the debt), the local government debt (the debt of municipal enterprises, nonbudgetary funds, budgetary and public enterprises) and the social security fund debt (the debt of the State Social Insurance Fund, the Mandatory Health Insurance Fund and other subjects within this sector).

The state may borrow in several ways. The main means of the government borrowing is the Government securities (abbreviated GS). The Ministry of Finance of the Republic of Lithuania describes the Government securities as debt securities issued on behalf of the country on the domestic (bonds, Treasury bills, saving 
certificates) or foreign markets (Eurobonds) attesting to the right of the holder thereof to obtain, within the time limits provided for, an amount corresponding to a nominal value thereof, an interest, or other equivalent. These securities may be purchased at the time of emission distribution or in the secondary market. The issuer of the Government securities is the Government of the Republic of Lithuania which borrows on behalf of the State and is represented by the Ministry of Finance of the Republic of Lithuania.

The Government securities are classified according to the duration: Treasury bills with a residual maturity shorter than one year and bonds with a residual maturity exceeding one year [19].

As for Eurobonds, they are distributed in the Government foreign markets, so it is denominated in the foreign currency. Currently, the secondary market provides Eurobonds denominated in euros, US dollars and Swiss francs [20].

The saving bonds differ from other securities as they are intended for retail investors, i.e., for all residents as a safe alternative of investments. Residents wishing to purchase saving bonds do not pay the fee of transaction related to securities acquisition, the storage of saving bonds, securities account opening. All these fees shall be paid by the Ministry of Finance. Residents may purchase these securities themselves directly while investing in the other above mentioned Government securities (bonds, State Treasury bills or Eurobonds) by applying to financial brokerage units of commercial banks or to any relevant finance broker company. Saving bonds are distributed to the period of 1, 2 and 3 years [21].

Another means of borrowing is a direct loan. The Government, through the Ministry of Finance, may also borrow and take loans from the domestic and the foreign credit institutions and the international financial institutions, such as the International Monetary Fund (IMF), the Nordic Investment Bank, the European Investment Bank and others. The Government may also borrow from the state and municipality companies or other companies where the state or municipal authorities may have a significant impact.

\section{Critical analysis of management tendencies of public debt}

Failing to ensure the balanced budget and with the constant deficit of the budget, the Government of Lithuania has been forced to increase the need of borrowing and the public debt every year. The tendencies of the Lithuanian public debt are shown in Figure 2.

The presented data show that the constant grow of the public debt is observed in Lithuania. In the period before the crisis (from 2004 to 2008), when there was a high rate of growth of our country's economy, the public debt increased by almost 43 percent (from LTL 12,15 billion to LTL 17,37 billion); while observing the key indicator - the debt ratio to GDP - during those five years, this ratio gradually decreased (due to rapidly rising GDP). Because of the earlier mentioned negative 
factors of economic recession and the increased borrowing needs, there was a marked increase in the debt from 2009 to 2012. The debt in 2013, compared to the debt in 2008, increased by 2,7 times - up to LTL 46,95 billion (that is the rate almost comparable to those of even two annual budgets of Lithuania), which accounted for 39 percent of GDP. Counting from 2004 to 2013, the Lithuanian capital debts increased by about LTL 35 billion.

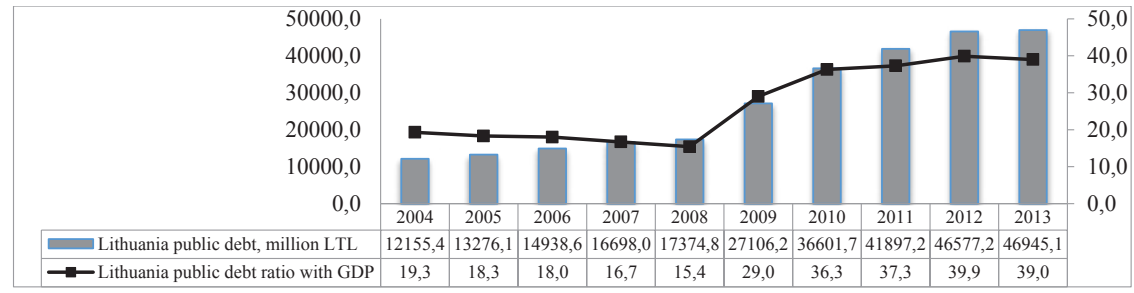

Figure 2. Public debt and its ratio to GDP

Source: compiled by the author on the data of the Ministry of Finance [22] and the Department of Statistics [16]

Assessing the upward tendency of the public debt, the majority of politicians, scientists and public figures claim that the level of the public debt is acceptable and even low enough - 40 percent of GDP profit debt is not only much lower than the level of 60 percent of GDP established in the Maastricht Treaty, but also it is lower than the average of the European Union countries, which was amounted to 85,4 percent of GDP in 2013 (see Figure 3). Economic downturn has highlighted a rather different kind of problems in public finance sector. A difficult situation has formed in the EU, where a number of euro zone countries are suffering from fiscal imbalances determined by the largest public debt in history [27].

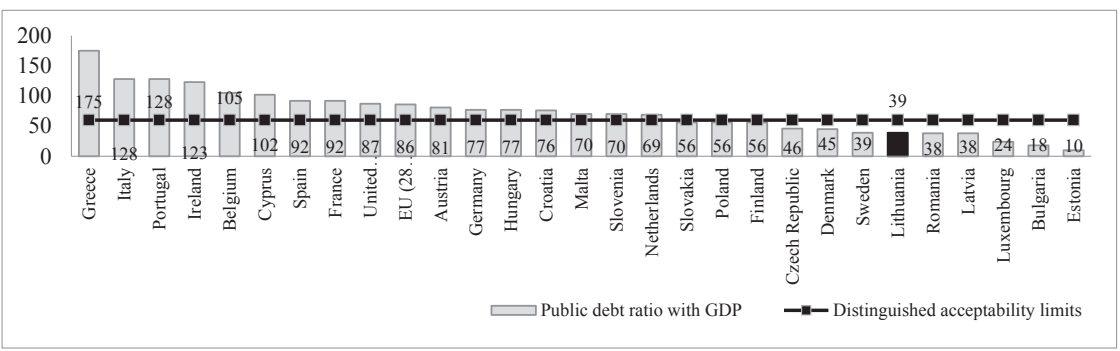

Figure 3. Comparison of EU countries public debt in 2013, in percent of GDP

Source: compiled by the author on the data of Eurostat [8] 
However, these arguments for an "acceptable" level of the public debt are unfounded. In particular, it should be recalled that Lithuania did not inherit any debts when independence was regained - Lithuania has begun to form and accumulate the public debt only since 1993, while other European countries have their debt began to "grow" much earlier. Therefore, to assess the level of acceptability of the Lithuania public debt comparing it with other European countries would be unfair. According to Karazijienè [11], [12], the Maastricht criteria set the maximum limit of the debt, hence, according to the mere fact that the public debt satisfies this criterion, there is no basis to claim that the burden of the public debt is acceptable.

Within 20 years, Lithuania has increased its public debt to LTL 47 billion and since 2014 and for the following years even a higher requirement for borrowing is planned (mainly for the older debt refinancing). The growing tendency of the Government borrowing should be seen as a negative fact because Lithuania managed to accumulate the debt equal to almost two annual national budgets in a rather short period of time. Looking to the future and considering the unstable economic and financial situation in the Eurozone, the alarm should be taken into consideration because if Lithuania faced the new economic shocks, our state would really meet extreme difficulties on its debt obligations and debt repayment.

The fact should also be mentioned that the largest part of money borrowed by the Government is not invested but is designated to cover the deficit of the budget and service costs of the debt (see Figure 4) and earlier debt refinancing. Therefore, it is only an ever-increasing debt burden that reduces the potential investments to the Lithuanian economy in general and to its economic growth.

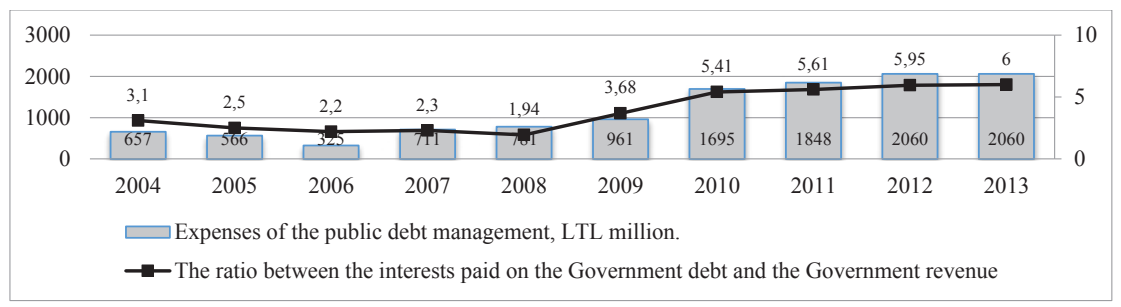

\section{Figure 4. Management expenditure of the public debt and the ratio between the interests paid on the Government debt and the Government revenue}

Source: compiled by the author

The growing tendency of this very important indicator means not only that Lithuania borrows overpriced, but also the fact that more and more money (about LTL 2 billion in this case) which the government could designate for development of economic and other important areas will be only designated to pay the cost of the public debt. 
Analysing assessment indicators of the public debt, their values will be compared with the critical values which are set out in the Maastricht Treaty, by the International Monetary Fund and the World Bank. When the critical limits are exceeded, the public debt becomes a dangerous phenomenon for the state and there is a risk that the country will not be able to meet its obligations in the future. Limit values of the indicators are presented in Table 2 .

Table 2. Evaluation criteria of public debt acceptability level

\begin{tabular}{|l|l|l|}
\hline \multicolumn{1}{|c|}{ Criteria } & \multicolumn{1}{|c|}{ Definition of criteria } & $\begin{array}{l}\text { Distinguished acceptability } \\
\text { limits }\end{array}$ \\
\hline Public debt and GDP ratio & $\begin{array}{l}\text { Provide country's economic } \\
\text { stability level. }\end{array}$ & $\begin{array}{l}\leq 60 \text { percent GDP } \\
\text { (Maastricht Treaty criteria) }\end{array}$ \\
\hline Foreign debt and GDP ratio & $\begin{array}{l}\text { Country's potentiality to } \\
\text { return debts is assessed. }\end{array}$ & $\begin{array}{l}\leq 30 \text { percent } \\
\text { (IMF) }\end{array}$ \\
\hline $\begin{array}{l}\text { Ratio of paid interest on } \\
\text { government debt and } \\
\text { government's revenues }\end{array}$ & $\begin{array}{l}\text { The burden of country's debt } \\
\text { is assessed. }\end{array}$ & $\begin{array}{l}\leq 10 \text { percent } \\
\text { (IMF) }\end{array}$ \\
\hline $\begin{array}{l}\text { Budget deficit and GDP } \\
\text { ratio, \% }\end{array}$ & $\begin{array}{l}\text { Country's financial situation } \\
\text { is assessed. }\end{array}$ & $\begin{array}{l}\geq 3 \text { percent } \\
\text { (Maastricht Treaty criteria) }\end{array}$ \\
\hline
\end{tabular}

Source: compiled by the author

Indicators of the Lithuanian public debt in 2004-2013 are presented in Table 3. The bold field indicates the year when the corresponding indicator of the Lithuanian debt exceeded the critical limit compared with the indicators set out in Table 2.

Table 3. Acceptability indicators of Lithuanian public debt, \%

\begin{tabular}{|l|c|c|c|c|c|c|c|c|c|c|}
\hline \multicolumn{1}{|c|}{ Indicators|Year } & $\mathbf{2 0 0 4}$ & $\mathbf{2 0 0 5}$ & $\mathbf{2 0 0 6}$ & $\mathbf{2 0 0 7}$ & $\mathbf{2 0 0 8}$ & $\mathbf{2 0 0 9}$ & $\mathbf{2 0 1 0}$ & $\mathbf{2 0 1 1}$ & $\mathbf{2 0 1 2}$ & $\mathbf{2 0 1 3}$ \\
\hline $\begin{array}{l}\text { Budget deficit and GDP } \\
\text { ratio, \% }\end{array}$ & 1,5 & 0,5 & 0,4 & 1,0 & $\mathbf{3 , 3}$ & $\mathbf{9 , 4}$ & $\mathbf{7 , 2}$ & $\mathbf{5 , 5}$ & $\mathbf{3 , 2}$ & 2,6 \\
\hline $\begin{array}{l}\text { Public debt and GDP ratio } \\
\text { Ratio of paid interest on } \\
\text { government debt and } \\
\text { government's revenues }\end{array}$ & 3,1 & 2,5 & 2,2 & 2,3 & 1,94 & 3,68 & 5,41 & 5,61 & 5,95 & 6,0 \\
\hline Foreign debt and GDP ratio & 11,90 & 11,05 & 12,29 & 11,20 & 9,89 & 20,48 & 27,85 & 28,65 & $\mathbf{3 0 , 6 2}$ & 27,15 \\
\hline
\end{tabular}

Source: compiled by the author

Data provided in Table 3 and Figure 5 indicate that the biggest problems in Lithuania to ensure the deficit of the budget are not bigger than 3 percent of GDP and this indicator exceeded the critical limit from 2008 to 2012. Budget deficits are 
financed by public borrowing, which increases the stock of public debt already in existence [5].

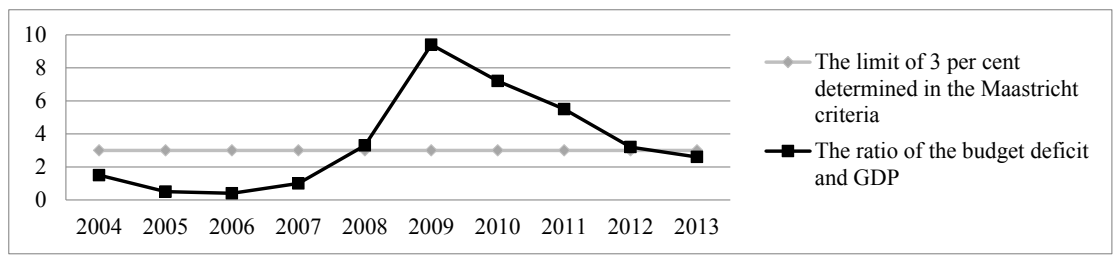

Figure 5. Ratio of budget deficit and GDP

Source: compiled by the author

Analysing indicators of the foreign debt, a big leap and their growth has been observed since 2009. It is the relative indicator of the foreign debt and GDP because it shows that the state will be able in the future to meet its foreign liabilities.

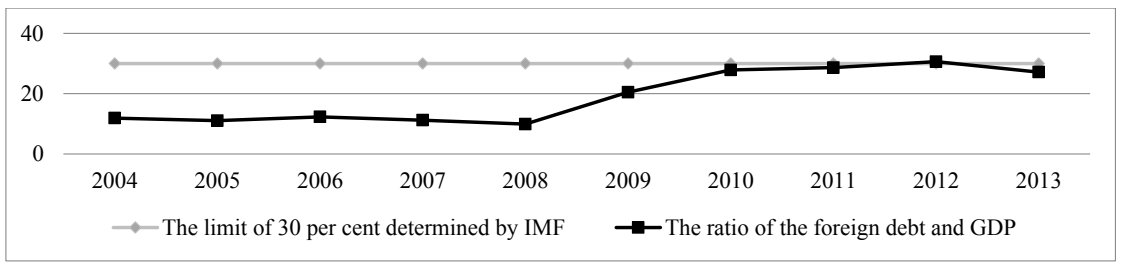

Figure 6. Ratio comparison of foreign debt and GDP with a limit determined by IMF

Source: compiled by the author

Data provided in Figure 6 indicate that the indicator value was increasingly approaching to the critical limit and exceeded it in 2012 because of the rapid growth of the foreign debt since 2009. Although a decline of this indicator was identified in 2013, it still remained near to the limit. It means that the Lithuanian public foreign debt in the future can become large enough to burden our state and it can be difficult to meet foreign liabilities.

After the critical analysis of the Lithuanian public debt of acceptability, indicators will continue to be predictable and compared sizes of the public debt in 2014-2017. Scientists offer a variety of mathematical models that may predict and assess a reasonable amount of the public debt concerning the current macroeconomic situation in the country. Mathematical models of A. Domar and O. Blanchard will be adapted to this article.

The acceptable size of the public debt in time $t$, according to O. Blanchards [3] mathematical model, is determined by the formula No. 1 . 


$$
b_{t}=\frac{1+i}{1+y} b_{t-1}+p d_{t}+s f_{t}
$$

Where: $b_{t}-$ public debt and GDP ratio in time t, $\%$;

$\psi-$ nominal GDP growth rate, $\%$;

$\mathrm{i}$ - country's borrowing interest norm, $\%$;

$\mathrm{pd}_{\mathrm{t}}-$ country's initial budget balance and GDP ratio in time (t), \%;

$\mathrm{sf}_{\mathrm{t}}$ - adjusted ratio of income and cost difference with GDP in time (t), $\%$.

F. Breuss [4] stated that A. Domar, analysing the impact and burden of the public debt on the macroeconomic processes of the country, was one among the first ones who suggested using the mathematical modelling by determining and predicting the reasonable amount of the public debt of GDP. He suggested a formula that can identify and predict the level of the public debt in the short-term period (see Formula 2):

$$
b_{t}-b_{t-1}=-\frac{\psi}{1+\psi} b_{t-1}+\frac{d}{1+\psi}
$$

Where: $\mathrm{b}_{\mathrm{t}}-$ ratio of the public debt and GDP in time $t, \%$;

$\psi-$ nominal rate of GDP growth, $\%$;

$\mathrm{d}$ - ratio of the budget deficit and nominal GDP, \%.

Calculating the predicted values, the macroeconomic projections of indicators provided by the Ministry of Finance [9] and the Convergence of Lithuania in the 2014 programme [18] will be used. These indicator projections of the public debt do not include the planned funding in order to manage the risk of refinancing by the redemption of Eurobond emissions. The amount value of the public debt calculated according to the mathematical models is provided in Table 4.

Table 4. Projections of macroeconomic indicators

\begin{tabular}{|l|c|c|c|c|c|}
\hline \multicolumn{1}{|c|}{ Indicators|Year } & $\mathbf{2 0 1 3}$ & $\mathbf{2 0 1 4}$ & $\mathbf{2 0 1 5}$ & $\mathbf{2 0 1 6}$ & $\mathbf{2 0 1 7}$ \\
\hline Public debt of GDP, \% & 39,4 & 38,8 & 38,1 & 35,3 & 31,7 \\
\hline Nominal GDP growing, \% & & 4,7 & 5,5 & 6,4 & 7,4 \\
\hline Implicit interest rate, \% & & 4,7 & 4,0 & 3,9 & 4,4 \\
\hline Primary balance & & $-0,1$ & 0,7 & 1,6 & 2,5 \\
\hline Budget deficit of GDP, \% & - & 39,50 & 37,55 & 35,60 & 31,81 \\
\hline $\begin{array}{l}\text { Estimated ratio value of public debt and GDP by the } \\
\text { mathematical method of Blanchard }\end{array}$ & - & 39,44 & 37,63 & 35,72 & 31,85 \\
\hline $\begin{array}{l}\text { Estimated ratio value of public debt and GDP by the } \\
\text { mathematical method of Domar }\end{array}$ & - & & & 0,1 \\
\hline
\end{tabular}

Source: compiled by the author 
The results obtained are compared with projections estimated by the Ministry of Finance and provided in Figure 7.

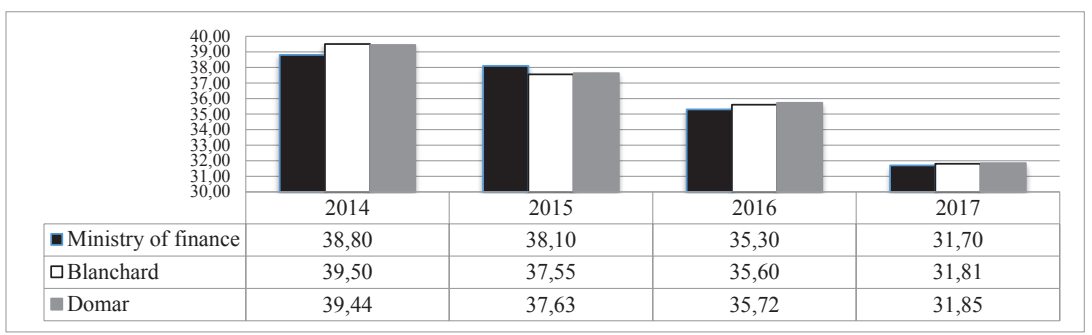

Figure 7. Projection comparison of calculated public debt amount, \% of GDP

Source: compiled by the author

Table 4 and Figure 7 show that the amount of the public debt calculated by Blanchard and Domar is very similar to projections indicated by the Ministry of Finance. It can be stated that the ratio of the public debt and GDP will take a downward tendency in 2015 if all the predicted macroeconomic indicators are reached.

After calculation and comparison of the results, it can be said that these mathematical models are sufficiently accurate and can be useful in modelling, planning and predicting the public debt and borrowing consequences. The optimal amount of the public debt at certain or desired macroeconomic indicators and conditions may be predicted by using these models. This prediction is very useful and even necessary in forming the borrowing policy of the country.

\section{Conclusions}

1. If the Government wants to ensure the effective policy of the debt management, it must clearly define the strategy of the debt management, objectives and the management system of the debt risk. It is the only way to reduce the cost of the debt serving and positively affect the economic development of the country.

2. The analysis of the macroeconomic indicators revealed that Lithuania failed to collect the balanced budget during the analysed period. This was determined by yearly increasing government spending which grew the borrowing requirement. Such spending policy implemented complicated the economic situation in Lithuania in the beginning of the crisis and had a significant impact for the growth of the public debt.

3. The indicator analysis of the Lithuanian public debt revealed the negative growing tendency of the debt. The constant deficit of the budget even in good economic times forced the government to increase its borrowing and the public debt 
every year. The debt increased by almost 43 percent (from LTL 12,15 billion to LTL 17,27 billion) from 2004 to 2008, the debt increased by 2,7 times in 2013 compared with 2008 (up to LTL 46,35 billion). The Lithuanian public debt increased by about LTL 35 billion in over the decade from 2004 to 2013.

4. Accounting for the fact that the largest part of money borrowed by the Government is not invested but is designated to cover the deficit of the budget and service costs of the debt and earlier debt refinancing, it can be stated that such a rapid growth tendency of the debt not only stops the economic growth in Lithuania, but is ever-increasing the burden of the debt and reduces potential investments in the Lithuanian economy in general and to the economic growth.

5. The mathematic modelling of the Lithuanian public debt projections showed that since 2015 part of the Lithuanian public debt of GDP is expected to take a downward tendency if the predicted macroeconomic indicators are achieved and sustained.

\section{References}

1. Alechin, B.I. Gosudarstvenij dolg. Moscow: 2007.

2. Barro, R.J. Macroeconomics: A Modern Approach. Thomson South-Western, 2008.

3. Blanchard, O. Makroekonomika. Vilnius: Tyto Alba, 2007.

4. Breuss, F. Sustainability of the Fiscal Criteria in Stage III of the EMU. IEF Working Paper Nr. 29, 1998, p. 5-6 [interactive]. [accessed on 2015-02-10]. <http://core.kmi.open. ac.uk/download/pdf/11006843.pdf>.Burda, M., and Wyplosz, Ch. Macroeconomics: A European Text. Oxford University, 2013.

5. Buškevičiūte, E. Viešieji finansai. Kaunas: Technologija, 2008.

6. Davulis, G. Ekonomikos teorija. Vilnius: Mykolo Romerio universiteto leidybos centras, 2009.

7. Eurostat. Statistics Database [interactive]. [accessed on 2015-02-27]. <http://ec.europa. eu/eurostat/data/database $>$.

8. Finansu ministerija. Lietuvos ekonominiu rodikliu projekcijos [interactive]. [accessed on 2015-02-10]. <http://www.finmin.lt/web/finmin /aktualus_duomenys/makroekonomika $>$.Frederic, S. Macroeconomics Policy and Practice. Pearson Education Limited, 2012.

9. Karazijienè, Ž. The State's Debt Acceptance Criteria Identification and Evaluation of Their Acceptability in Lithuania. Verslo sistemos ir ekonomika. Vilnius: Mykolo Romerio universitetas, 2014, 4(1): 43-52.

10. Karazijienè, Ž. Valstybès skolinimosi poreikio projektavimo galimybès. Practice and Research in Private and Public Sector - 2013: 3rd International Scientific Conference: Conference Proceedings. 2013, April 11-12. Vilnius: Mykolo Romerio universitetas, 2013, p. 379-387.

11. Karazijienè, Ž., and Sabonienè, A. Valstybès skolos struktūra ir valstybės skolinimosi ịtaka Lietuvos ekonomikai. Ekonomika ir vadyba. 2009, 14: 272.

12. Kindsfaterienè, K., and Lukaševičius, K. The Impact of the Tax System on Business Environment. Inžinerinè Ekonomika. 2008, (57): 70-77. 
13. Levišauskaitè, K., and Rūškys, G. Valstybès finansai. Kaunas: Vytauto Didžiojo universiteto leidykla, 2003.

14. Statistics Lithuania. General Government Deficit and Debt [interactive]. [accessed on 2015-02-15]. <http://web.stat.gov.lt/en/pages/view/?id=1379\&PHPSESSID=af1a6857ad af29eb5079e0ee38ecfa7b>.Lietuvos Respublikos valstybès skolos įstatymas. Valstybès žinios. 2004, Nr. 4-31.

15. Lietuvos konvergencijos 2014 metu programa [interactive]. [accessed on 2015-02-15]. $<$ http://www.finmin.lt/finmin.lt/failai/vykdoma_politika/Konvergencijos_programa_2014_LT.pdf $>$.LR finansų ministerija. Investavimas $i$ Vyriausybés vertybinius popierius [interactive]. [accessed on 2015-02-15]. <http://www.finmin.lt/c/portal/ layout?p_1_id=PUB.1.68>.LR finansų ministerija. Euroobligacijos [interactive]. [accessed on 2015-02-15]. <http:/www.finmin.lt/web/finmin/vvp/euroobligacijos>.LR finansų ministerija. Taupymo lakštai [interactive]. [accessed on 2015-02-15]. <http://www. finmin.lt/web/finmin/vyriausybes_vertybiniai_popieriai/tl $>$.General Government Debt 2008-2013 [interactive]. [accessed on 2015-01-28]. <http://www.finmin.lt/web/ finmin/leidiniai/skola>.

16. Mankiw, N.G., and Taylor, P. Economics. Thomson, 2006.

17. Navickas, V., and Malakauskaitè, A. Nauji makroekonominès politikos svertai: klasterių fenomenas. Verslas: teorija ir praktika. 2008, 4: 245-252.

18. Snieška, V., et al. Makroekonomika. Kaunas: "Technologija”, 2005.

19. Štuopytė, Ž., and Guzavičius, A. The Forecast of the State Admissible Borrowing Limits: The Case of Lithuania. Transformations in Business \& Economics. 2008, 2(7, 14), Supplement B: 130-142.

20. Vaicenavičius, T., and Račikas, E. Valstybės skolos vertinimo teoriniai ir praktiniai aspektai Europos Sąjungos šalių kontekste. Ekonomika ir vadyba: aktualijos ir perspektyvos. 2013, 1(29): 38-50.

\section{Žaneta Karazijienè}

\section{Valstybės skolos ir jos valdymo tendencijų kritinė analizė}

\section{Anotacija}

Valstybės skola užima svarbią vietą bet kurios šalies makroekonominėje sistemoje. Taip yra todèl, kad skolos formavimosi ir jos aptarnavimo procesai labai stipriai veikia valstybès finansų sistemą, šalies investicinị klimatą, vartojimo struktūrą ir tarptautinio bendradarbiavimo raidą. Dažniausiai valstybės skolos atsiradimo ir didejjimo priežastimi tampa šalyje egzistuojanti politika, kuri negali užtikrinti stabilaus valstybės pajamų ir išlaidų balanso. Šiame straipsnyje tiriama valstybės skolos valdymo teorinių konceptų ịvairovè, mokslininkų požiūris ị valstybès skolą, analizuojami valstybès skolos priimtinumo vertinimo kritiniai rodikliai, kurie parenkami pagal Mastrichto sutartyje apibrěžtus rodiklius bei remiantis Tarptautinio valiutos fondo ir Pasaulio banko reikalavimais. Remiantis identifikuotais valstybès skolos priimtinumo kritiniais rodikliais atliekama Lietuvos valstybès skolinimosi tendencijų kritinè analizė ir rodiklių vertinimas. Gauti tyrimų rezultatai atskleidè, kad Lietuvoje dažnai nesilaikoma Mastrichto sutartyje numatytų arba Tarptautinio valiutos fondo ir Pasaulio banko patvirtintų kriterijų. Atliktas Lietuvos valstybės skolos projekcijų matematinis modeliavimas parodè, kad ateityje tikètina Lietuvos valstybès skolos dalies nuo BVP teigiama mažèjimo tendencija. 
Žaneta Karazijiené - Mykolo Romerio universiteto Ekonomikos ir finansų valdymo fakulteto, Ekonomikos ir verslo instituto docentè, socialinių mokslų (ekonomikos krypties) daktarè.

E.paštas zkarazijiene@mruni.eu

Žaneta Karazijiene - Mykolas Romeris University, Faculty of Economics and Finance Management, Institute of Economics and Management, Associate Professor.

E-mail zkarazijiene@mruni.eu

Straipsnis įteiktas redakcijai 2015 m. balandžio mèn.; recenzuotas; parengtas spaudai 2015 m. birželio mèn. 